\title{
Socioeducational gaps derived from the impact of digitization in Spain 2020
}

\section{Las brechas socioeducativas derivadas del impacto de la digitalización en España 2020}

\author{
Inés María González Vidal \\ Universidad de Santiago de Compostela. Santiago de Compostela, España \\ inesmaria.gonzalez@rai.usc.es \\ Adriana Gewerc Barujel \\ Universidad de Santiago de Compostela. Santiago de Compostela, España \\ adriana.gewerc@usc.es
}

\begin{abstract}
The COVID-19 pandemic visualized how digital assets influence contemporary society and play a decisive role in economic recovery. The objective of this work is to identify the social and educational gaps derived from the impact of the level of digitization in Spain 2020. This research is based on comparative education as methodological, relational and critical with the technological implementation; who tries to link education with changes in their social environment; in order to contribute to the improvement of the educational system. In this sense, based on the DESI report for the last three years, the case of Spain is analyzed in relation to the average score of the rest of the EU member countries. The social gaps pointed to profiles of vulnerable populations for having few digital skills or for being practically excluded from digital services and resources, achieving a new perspective centered on the human being will mean achieving economic development. The educational gaps pointed to Human Capital and its low skills in software, few specialists in ICT specialties and low female representation in ICT specialties. These results showed the importance of STEM and gender-sensitive education, which appears to be the key to economic growth and national competitiveness.
\end{abstract}

Key words: University and digital society, DESI; digital skills; STEM; gender.

\section{Resumen}

La pandemia de COVID-19 visualizó cómo los activos digitales influyen en la sociedad contemporánea y juegan un papel decisivo en la recuperación económica. El objetivo de este trabajo es identificar las brechas sociales y educativas derivadas del impacto del nivel de digitalización en España 2020. Esta investigación se basa en la educación comparada como metodológica, relacional y crítica con implementación tecnológica; que intenta vincular la educación con los cambios en su entorno social; con el fin de contribuir a la mejora del sistema educativo. En este sentido, a partir del informe DESI de los últimos tres años, se analiza el caso de España en relación con la puntuación media del resto de países miembros de la UE. Las brechas sociales apuntaban a perfiles de población vulnerable por tener pocas competencias digitales o por estar prácticamente excluida de los servicios y recursos digitales, lograr una nueva 
perspectiva centrada en el ser humano significa lograr el desarrollo económico. Las brechas educativas apuntaban al Capital Humano y sus bajas competencias en software, pocos especialistas en especialidades TIC y baja representación femenina en especialidades TIC. Estos resultados mostraron la importancia de la educación STEM sensible al género, que parece ser la clave para el crecimiento económico y la competitividad nacional.

Palabras clave: Universidad y sociedad digital, DESI; habilidades digitales; CTIM; género.

\section{Introduction}

The COVID-19 pandemic has generated in some countries the opportunity to implement different normative tools and connectivity policies to improve Internet access (Bhandari, 2020). In this sense, recent studies link Internet connectivity with greater opportunities to use digital skills, Internet services, digital technology, and digital public services (Bryndin, 2019). Consequently, those with inadequate Internet connectivity will be at a disadvantage and experience greater digital exclusion (Seifert, 2020). Likewise, some population profiles are practically excluded from digital services and resources because they do not have the means or do not have the necessary skills to participate in a digitally dominated society (Seifert, Cotten, \& Xie, 2020).

At present it is a fact, the change of the system of physical, socioeconomic and cultural relationships in the world for digitally connected relationships in a network (Cinnamon, 2020). There is an emerging interest of corporations in regulating multiple spheres of social life, immaterial biopolitical production emerges ${ }^{1}$ (Hardt \& Negri, 2000). Social interaction is monetized, converting interactions, affinities and social, emotional, political, family and physical relationships into data, metadata, attention, affection and commitment, all captured and sold to advertising companies (Van Dijck, 2013).

Technological innovation improves the quality of life in developing countries, and jobs related to STEM content are at the forefront of the diffusion of innovations, constituting a key factor for economic growth and national competitiveness (Gil-Galván, Martín-Espinosa \& Gil-Galvan, 2021; Bianchi \& Giorcelli, 2020). Hence, experts in the fields of labor economics have been warning about the impact of technological change on productivity, worker skills, and outsourcing decisions, as well as the importance of using updated formal

1 Biopolitics is a term coined by the political scientist Michel Foucault, it refers to an intersectional field between human biology and politics that takes as its theme the administration of life and the populations of a locality (Foucault, 1976). Intangible biopolitical production refers to production starting from social life itself, where the economic, the political and the cultural increasingly overlap and production is no longer a limited social sphere, since value is produced outside the factory by capturing the totality of social life (Hardt and Negri, 2000). 
training programs (Bianchi \& Giorcelli, 2019; Deming \& Noray, 2020; Crespí \& GarcíaRamos, 2021).

In this context, the need arises to deepen how the rapid growth in the vertiginous level of digitization of a country is affecting the processes of social and educational exclusion (Kwilinski, Vyshnevskyi \& Dzwigol, 2020; Martínez Usoralde, 2020). The goal of this work is to identify the social and educational gaps derived from the impact of the level of digitization in Spain 2020. It is based on a methodology in comparative education (Adick, 2018; Martí Marco, 2019; Mombelli, 2019). The behavior of the DESI in Spain for the period from 2018 to 2020 is analyzed and compared with the European average score. Next, with an exploratory and descriptive nature of the Spanish DESI 2020 report, the dimensions are contrasted, to identify possible social and educational gaps derived from the impact of the level of digitization in Spain (Russo, 2020).

The Digital Economy and Society Index is a complex variable composed of five fundamental dimensions, namely: Connectivity; Human capital; Use of Internet services; Integration of digital technology; and digital public services. The results confirmed the largest gap referred to Human Capital in relation to the rest of the dimensions. The main findings are related to low software skills, few specialists in ICT specialties and even very low values of female representation in ICT specialties. Based on these results, this work contributes to highlighting the importance of the involvement of STEM and gender-sensitive education in university environments, to reduce the impact of the vertiginous growth in the level of digitization of the country.

\subsection{Related work}

The growth of technological innovations has made it possible to raise the levels of networks and connections from home and mobile phones. High levels of connectivity have influenced the creation of new economies and have generated new skills and digital competencies required for Human Capital in an increasingly globalized labor market (Bryndin, 2019). Economic growth and the formation of Human Capital have implications for the knowledge economy, which is why a new perspective centered on the human being is essential (Flores, $\mathrm{Xu} \& \mathrm{Lu}, 2020)$. Experts in the fields of labor economics and employee training have been warning about the impact of technological change on productivity, worker skills, and outsourcing decisions, as well as the importance of using formal training programs (López \& Valley, 2006).

Internet consolidation enables a group of organizations to exercise greater control over Internet infrastructures and services. These organizations easily reach a large market of users,

Socio-educational gaps derived from the impact of digitization in Spain 2020 point to a STEM and gender-sensitive education. Inés M. González Vidal \& Adriana Gewerc Barujel. Página 3 de 24 
causing the network effect ${ }^{2}$ that increases the value of the service ${ }^{3}$ and can lead to an asymmetry of power, which in turn can be reflected in various aspects of the service (Arkko, 2020).

At present, digital public services and e-government have not explicitly considered different perspectives on citizens as users of these services. The need arises to explore new conceptualizations of the citizen as a user of digital public services (Distel \& Lindgren, 2019). In this sense, a new human-centered perspective will mean achieving economic development, but also solving social challenges and allowing people to enjoy an adequate quality of life. For this, it will be necessary to carry out a fusion of cyberspace and the real world, generate quality data and from there create new models, values and solutions to solve challenges. In the countries of the European Union (EU) with higher levels of digitization, a significant reduction in poverty and social exclusion is observed (Kwilinski, Vyshnevskyi \& Dzwigol, 2020). This analysis shows that the concepts of social inclusion can be better understood by examining the meaning and connotation of its opposite category, social exclusion (Anttiroiko \& de Jong, 2020).

From the educational point of view, innovation is a fundamental factor in the quality of organizations, together with the use of ICT as a means of training, they constitute the most important elements to highlight in the processes in a contemporary society (Mendoza Gamiño, 2019; Díaz, 2005; Sanci, 2020). The concept of social exclusion has strong connections with the issues of social justice, equity, equal results, equal opportunities, social cohesion and human capital (Anttiroiko \& de Jong, 2020). In this scenario, the relationship between social exclusion and technology is complex and multidimensional, and it can be strengthened because skills in information technology are intrinsically linked to technological innovation (Seifert, Cotten \& Xie, 2020).

Analyzing Human Capital from a training and educational perspective, the drastic variations in the needs of the labor market show an increase in the gap between education in STEM subjects and the new skills and competencies required of Human Capital (Psifidou \& Ranieri, 2020). This is since current university programs cannot be updated as quickly (Bianchi \& Giorcelli, 2019).

Within this framework, there is a need to promote better ICT learning programs that raise the level of ICT skills; thus, helping Spanish graduates to access an international job market and at the same time making our programs attractive to foreign university students (RoigVila, \& Moreno-Isac, 2020; Serra \& Roca-Piera, 2011). In short, new institutional policies are required that consider integration modalities, a new vision of the teaching and learning

2 The term network effect or network externality, in economics, is used to describe situations in which the consumption of one person directly influences the utility of another, either positive or negative (Chou \& Shy, 1990).

3 Metcalfe's law establishes that the value of a communications network is proportional to the square of the number of its users (Metcalfe, 2013). On the other hand, Zipf's law uses as a basis to justify the evaluation of a global network $n \log (n)$ where $n$ is the general size of a communications network (Briscoe, Odlyzko \& Tilly, 2006). 
process that integrates STEM content with interdisciplinary methods (Oppenheimer, Mills, Zakeri, Payte, Lidgi \& Zavala, 2020; Zapata-Ros and Lévy, 2018).

Within this framework, the impact of digitization in universities can be mitigated with an adequate symbiosis between the University and the STEM approach in teaching, allowing to update the scientific, mathematical and technological skills of students, with a view to improving digital skills required in the current labor market (Simó, Couso and Rodríguez, 2020).

In this sense, there is a need to promote better ICT learning programs that raise the level of ICT skills; thus, helping Spanish graduates to access an international job market and at the same time making our programs attractive to foreign university students (Roig-Vila, \& Moreno-Isac, 2020; Serra \& Roca-Piera, 2011). In short, new institutional policies are required that consider integration modalities, a new vision of the teaching and learning process that integrates STEM content with interdisciplinary methods (CEOE, 2017; Oppenheimer, Mills, Zakeri, Payte, Lidgi \& Zavala, 2020; Zapata - Ros and Lévy, 2018).

Even though some authors point out that the digital gender gap is narrowing in some contexts (Del Prete \& Almenara, 2020). Other current research points to the existence of a pronounced gender gap in STEM fields at the educational and labor market level (Johnson, MohrSchroeder, Moore \& English, 2020; Tellhed, Bäckström \& Björklund, 2017). In this sense, the gender approach in education is in constant investigation due to the long-term consequences on the personal and professional future of students (Hynes, Locher \& Donnet, 2020; García-Peñalvo, 2019).

Several studies have shown a direct relationship between university training and training for the labor market CEOE (2017). However, there are many different frameworks and points of view on this topic (Crespí \& García-Ramos, 2021; García-Peñalvo, 2020; Deming \& Noray, 2020; Flores, Xu \& Lu, 2020; Bryndin, 2019; Bianchi \& Giorcelli, 2019). In this sense, innovation and adaptation are the necessary elements in today's higher education infrastructures; it is imperative for the University to transform its way of thinking, not as factories of self-indulgent professionals, but as generators of valuable ideas with great influence and potential to manifest technologies and concepts that can cause positive changes in humanity (Crow, 2014).

\section{Materials and methods}

Digitization has improved the dissemination of scientific research, highlighting the possibility of comparative educational research (Powell, 2020). Comparatism is used in the educational field as a methodological, relational and critical operation with technological implementation, which recognizes the study of educational systems and processes of different nations and cultures, in order to improve the national educational system and consequently a benefit for society (Martí Marco, 2019).

Socio-educational gaps derived from the impact of digitization in Spain 2020 point to a STEM and gender-sensitive education. Inés M. González Vidal \& Adriana Gewerc Barujel. Página 5 de 24 
The analysis of digitization and its relationship with education helps us understand how educational processes should evolve (Mombelli, 2019). There are many possibilities of expansion of Comparative Education in new lines of research, in this sense, it is worth highlighting the importance of scientific research that allows monitoring reality and visualizing the great challenges facing the contemporary educational system (Adick, 2018). In this sense, this study was based on a comparative education methodology. The goal is to identify the social and educational gaps derived from the impact of the level of digitization in Spain 2020. To achieve our purpose, five research questions were developed.

Q1: What was the trend of the integration of digital technology in Spain in relation to the EU average, according to the DESI report in the period 2018-2019?

Q2: How was the evolution of Spanish human capital in relation to the EU average, according to the DESI report in the period 2018-2019?

Q3: What human capital requirements constitute the new digital skills required today according to the DESI report in the 2020 period?

Q4: What were the social and educational gaps derived from the impact of digitization in Spain 2020, if dimension 2Human capital is contrasted with the rest of the DESI 2020 dimensions (Q4.1: 1Connectivity; Q4.2: 3Use of Internet services; Q4.3: 4Integration of digital technology and Q4.4: 5Public services digital)?

Q5: How can the social and educational gaps derived from the impact of digitization in Spain 2020 be alleviated?

The data used comes from the DESI 2020 report, it should be noted that the results of the DESI report relate elements of the digitization of EU member states in times of pandemic. The DESI variable is made up of 5 dimensions: Connectivity; Human capital; Use of Internet services; Integration of digital technology; and digital public services (Russo, 2020). Table 1 shows the operationalization process specifying the complex variable DESI and its dimensions and indicators. In this study, a second reading of the data presented in this report is carried out. 
Table 1

Operationalization process. Source: By the author from Russo (2020).

\begin{tabular}{|c|c|c|}
\hline Variable & Dimensions & Indicators \\
\hline \multirow{11}{*}{$\begin{array}{l}\text { DESI } \\
2020, \\
\text { Digital } \\
\text { Economy } \\
\text { and } \\
\text { Society } \\
\text { Index }\end{array}$} & \multirow{3}{*}{1 Connectivity } & 1a Fixed broadband take-up; \\
\hline & & 1b Fixed broadband coverage; \\
\hline & & 1c Mobile broadband. \\
\hline & \multirow{2}{*}{2 Human capital } & 2a Internet user skills; \\
\hline & & 2b Advanced skills and development \\
\hline & \multirow{3}{*}{3 Use of Internet services } & 3a Internet use; \\
\hline & & 3b Activities online; \\
\hline & & 3c Transactions. \\
\hline & \multirow{2}{*}{$\begin{array}{l}4 \text { Integration of digital } \\
\text { technology }\end{array}$} & 4a Business digitization; \\
\hline & & 4b e-Commerce. \\
\hline & 5 Digital public services & 5a e-Government; \\
\hline
\end{tabular}

To achieve the objective of this study, a documentary analysis is carried out and a Related Works section is created. The behavior of the DESI in Spain for the period of three years (from 2018 to 2020) is analyzed and compared with the European average score, descriptive statistics are applied. Next, with an exploratory and descriptive nature of the Spanish DESI 2020, the dimensions are contrasted, to identify possible social and educational gaps derived from the impact of the level of digitization in Spain. Finally, the Results section is created.

\section{Results}

\subsection{DESI analysis in the period 2018-2020}

In the DESI report for the last three years, Spain has had a good ranking with a score above the European average. However, due to the high trend of digitization of society, it is necessary to deepen in some dimensions. In this sense, this study compares the DESI behavior of Spain in relation to the average score of the EU, in the period 2018-2020 (Table 2). 
Table 2

DESI dimensions in the 2018-2020 period. Source: based on data from Russo (2020).

\begin{tabular}{|c|c|c|c|c|c|c|c|c|c|c|c|c|}
\hline & \multicolumn{2}{|c|}{ DESI rank } & \multicolumn{2}{|c|}{ Connectivity } & \multicolumn{2}{|c|}{$\begin{array}{l}\text { Human } \\
\text { Capital }\end{array}$} & \multicolumn{2}{|c|}{$\begin{array}{c}\text { Use of } \\
\text { Internet } \\
\text { services }\end{array}$} & \multicolumn{2}{|c|}{$\begin{array}{c}\text { Integration } \\
\text { of digital } \\
\text { technology }\end{array}$} & \multicolumn{2}{|c|}{$\begin{array}{c}\text { Digital } \\
\text { public } \\
\text { services }\end{array}$} \\
\hline Years & $\begin{array}{l}\text { Spain } \\
\text { score }\end{array}$ & $\begin{array}{l}\text { EU } \\
\text { score }\end{array}$ & $\begin{array}{l}\text { Spain } \\
\text { score }\end{array}$ & $\begin{array}{l}\text { EU } \\
\text { score }\end{array}$ & $\begin{array}{l}\text { Spain } \\
\text { score }\end{array}$ & $\begin{array}{l}\text { EU } \\
\text { score }\end{array}$ & $\begin{array}{l}\text { Spain } \\
\text { score }\end{array}$ & $\begin{array}{l}\text { EU } \\
\text { score }\end{array}$ & $\begin{array}{l}\text { Spain } \\
\text { score }\end{array}$ & $\begin{array}{l}\text { EU } \\
\text { score }\end{array}$ & $\begin{array}{l}\text { Spai } \\
\mathrm{n} \\
\text { score }\end{array}$ & $\begin{array}{l}\text { EU } \\
\text { score }\end{array}$ \\
\hline 2020 & 57,5 & 52,6 & 60,8 & 50,1 & 47,6 & 49,3 & 60,8 & 58 & 41,2 & 41,4 & 87,3 & 72 \\
\hline 2019 & 53,6 & 49,4 & 55,4 & 44,7 & 44,5 & 47,9 & 55,1 & 55 & 41,3 & 39,8 & 80,9 & 67 \\
\hline 2018 & 50,2 & 46,5 & 45,9 & 39,9 & 44,9 & 47,9 & 52,1 & 51,8 & 41,1 & 37,8 & 76,6 & 61,8 \\
\hline
\end{tabular}

The Connectivity dimension is related to the adoption of fixed broadband, fixed broadband coverage, mobile broadband, and broadband prices. If we analyze the period 2018-2020, we find that Spain, in relation to the score of the EU countries, obtained a higher score. The same happened with the Use of Internet services, but with a more discreet difference, this dimension refers to the use that citizens make of Internet services and online transactions. In relation to e-Government, Spain presented a good performance in the Digital public services dimension, with a significant difference in relation to the EU (figure 1).

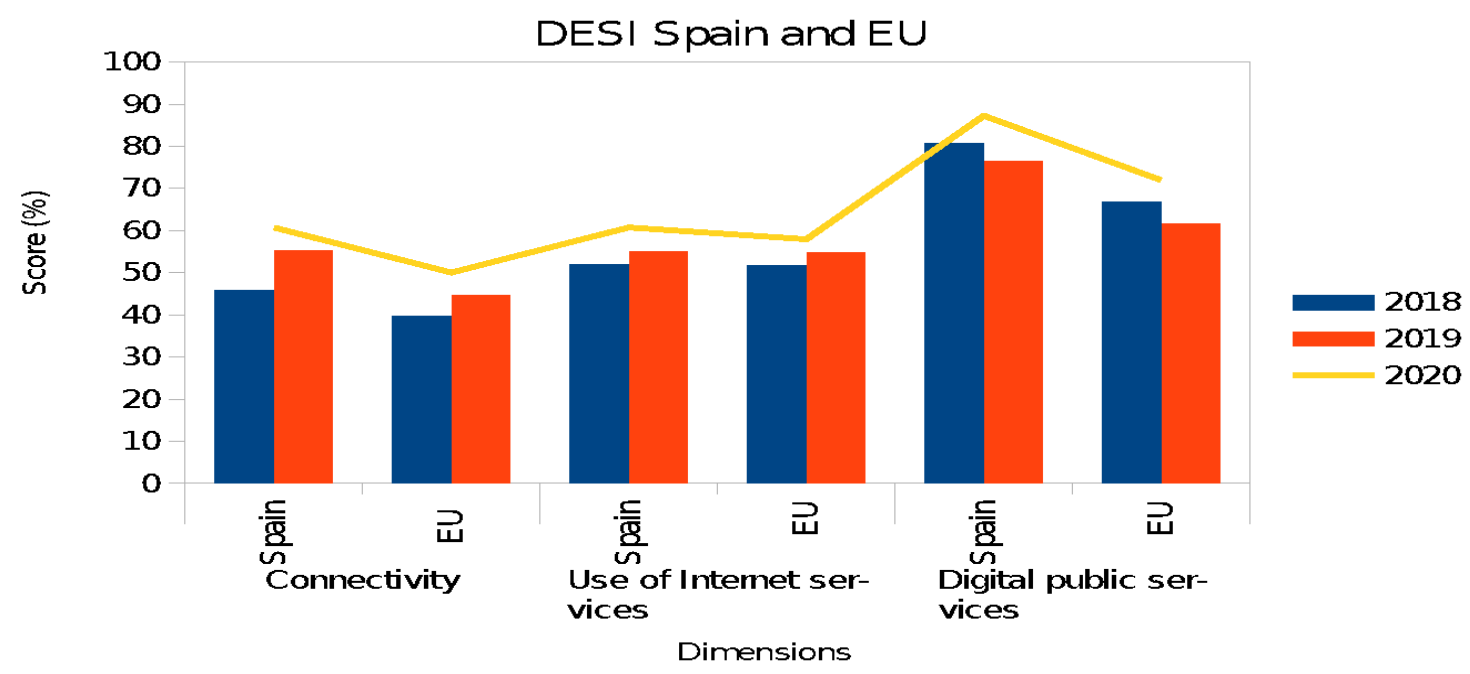

The Integration of digital technology dimension is related to business digitization and

Figure 1. Score of the dimensions: Connectivity, Use of Internet services and Digital public services. Source: based on data from Russo (2020) in LibreOffice Calc.

electronic commerce, analyzing the behavior of Spain in relation to the average of the EU countries, it is observed that the growth trend line was discretely positive, tending to the value null, contrasting with the results of the EU (figure 2).

Socio-educational gaps derived from the impact of digitization in Spain 2020 point to a STEM and gender-sensitive education. Inés M. González Vidal \& Adriana Gewerc Barujel. Página 8 de 24 


\section{Integration of digital technology}

Report for DESI Spain and EU

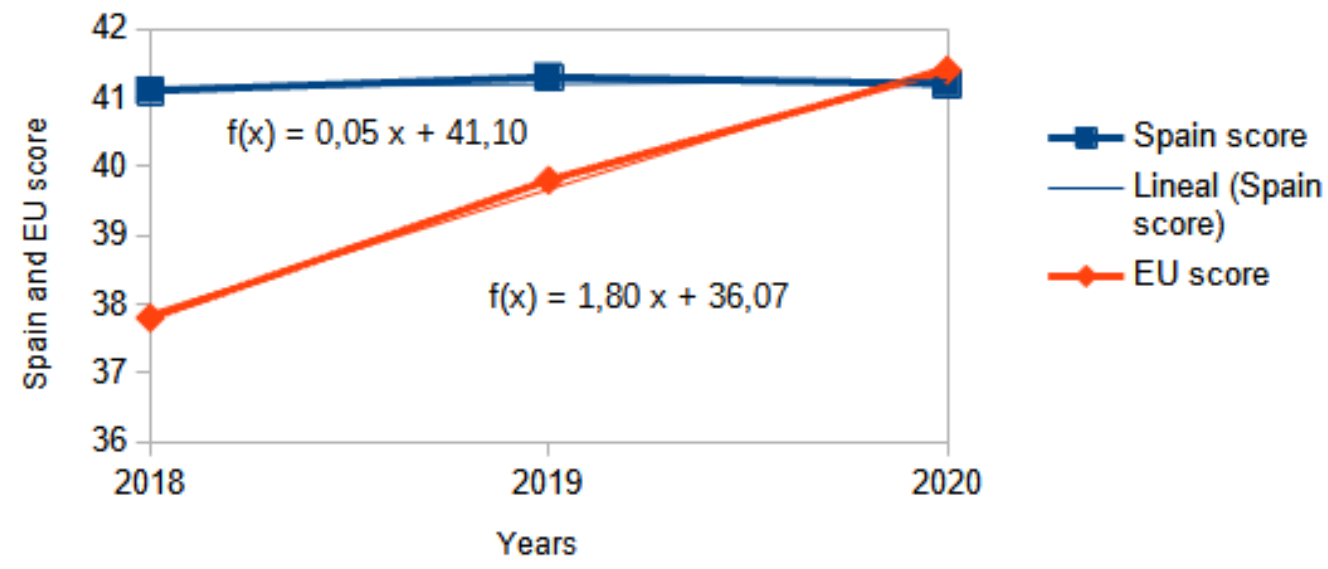

Figure 2 Dimension Integration of digital technology, Spain and EU average.

Source: based on data from Russo (2020) in LibreOffice Calc.

The dimension of Human capital (referring to the skills of Internet users and advanced skills) presents values below the EU (figure 3). Analyzing the last three years, the Human Capital indicator shows a negative trend line, although it is true that in the 2019-2020 period there is a slight upward trend.

Human capital

This Report for DESI Spain and EU

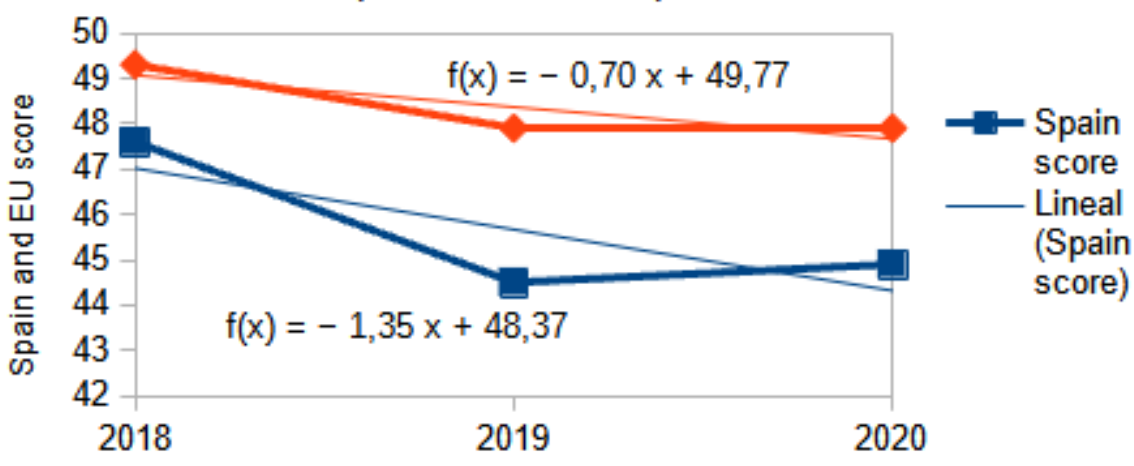

Figure 3 Dimension of Human, Spain and EU score.

Source: based on data from Russo (2020) in LibreOffice Calc.

statistic visualizes possible social and educational gaps mainly related to the Human Capital dimension and the Integration of digital technology in Spain. However, it seems that the analysis of digital competences constitutes the backbone of the digital society, they allow citizens to use digital services and participate in basic and less basic activities online.

Socio-educational gaps derived from the impact of digitization in Spain 2020 point to a STEM and gender-sensitive education. Inés M. González Vidal \& Adriana Gewerc Barujel. Página 9 de 24 


\subsection{DESI 2020 analysis for the Spanish case}

The results of the Related Works section and those of the previous section, indicate the need to deepen a new type of human capital referred to the new acquired digital skills (Psifidou \& Ranieri, 2020). The Human Capital dimension is made up of 6 indicators, which represent $2 \mathrm{a}$ Internet user skills and $2 \mathrm{~b}$ advanced skills. Possession of these skills creates income opportunities that allow people to move out of the poverty zone (Russo, 2020).

Table 3

Dimension of 2 Human Capital in DESI 2020 in Spain. Source: based on data from Russo (2020).

\begin{tabular}{|l|l|l|}
\hline No & Indicator & Spain score \\
\hline 1 & 2a1 At least basic digital skills & $57,00 \%$ \\
\hline 2 & 2a2 Above basic digital skills & $36,00 \%$ \\
\hline 3 & 2a3 At least basic software skills & $59,00 \%$ \\
\hline 4 & 2b1 ICT specialists & $3,20 \%$ \\
\hline 5 & 2b2 Female ICT specialists & $1,10 \%$ \\
\hline 6 & 2b3 ICT graduates & $4,00 \%$ \\
\hline
\end{tabular}

Table 3 shows the "basic" digital competencies in people when the following four dimensions are evaluated: information, communication, problem solving and software for content creation (measured by the number of activities carried out during the 3 months previous), was $57.00 \%$. Basic digital skills "above the basics" in each of the following four dimensions: information, communication, problem solving and software for content creation (measured by the number of activities carried out during the previous 3 months), was $36.00 \%$. The basic knowledge of software, in people who in addition to having used basic software functions such as word processors, have used advanced spreadsheet functions, have created a presentation or document that integrates text, images and tables or graphics, or a code written in a programming language, was $59.00 \%$. The hiring of ICT specialists, based on the ISCO-08 classification and includes positions such as ICT service managers, ICT professionals, ICT technicians, installers and ICT administrators, was 3.20\%. The number of women ICT specialists hired based on the ISCO-08 classification and includes positions such as ICT service managers, ICT professionals, ICT technicians, installers and ICT administrators, was only $1.10 \%$. Graduates in ICT, that is, people with a degree in ICT, 4.00\% (Russo, 2020; Kwilinski, Vyshnevskyi \& Dzwigol, 2020).

The human being is placed at the center of today's society, in this sense, digital skills are the backbone of the digital society. The drastic variations in the needs of the labor market caused by the impact of technological change on productivity and workers' skills show an increase

Socio-educational gaps derived from the impact of digitization in Spain 2020 point to a STEM and gender-sensitive education. Inés M. González Vidal \& Adriana Gewerc Barujel. Página 10 de 24 
in the gaps related to Human Capital. From an educational point of view, the formation of human capital appears to have great implications for the knowledge economy (Deming \& Noray, 2020; Crespí \& García-Ramos, 2021; Roig-Vila, \& Moreno-Isac, 2020; Serra \& Roca-Piera, 2011; García-Peñalvo, 2020).

\subsubsection{Connectivity}

The connectivity dimension refers to the supply of fixed broadband, fixed broadband coverage, mobile broadband, and broadband prices (Russo, 2020). It includes 8 indicators, having connectivity would provide the user with more opportunities to use digital skills, 1aInternet services, 1bdigital technology and 1cdigital public services (table 4).

Table 4

Dimension of 1Connectivity, DESI 2020 in Spain. Source: based on data from Russo (2020).

\begin{tabular}{|l|l|c|}
\hline No & Indicator & Spain score \\
\hline 1 & 1a1 Overall fixed broadband take-up & $78,00 \%$ \\
\hline 2 & $\begin{array}{l}\text { 1a2 At least 100 Mbps fixed broadband take-up } \\
1\end{array}$ & $53,00 \%$ \\
\hline 3 & $\begin{array}{l}\text { 1b1 Fast broadband (NGA) coverage } \\
\text { households }\end{array}$ & $90,00 \%$ \\
\hline 4 & $\begin{array}{l}\text { 1b2 Fixed Very High-Capacity Network } \\
\text { (VHCN) coverage, households }\end{array}$ & $89,00 \%$ \\
\hline 5 & 1c1 4G coverage, households & $95,00 \%$ \\
\hline 6 & 1c2 Mobile broadband take-up & $99,00 \%$ \\
\hline 7 & 1c3 5G readiness NA & $30,00 \%$ \\
\hline 8 & 1d1 Broadband price index & $51,00 \%$ \\
\hline
\end{tabular}

The Overall fixed broadband take-up is $78 \%$, and it means the $\%$ of households subscribing to fixed broadband. At least $100 \mathrm{Mbps}$ of fixed broadband coverage 53\%, this indicator represents the percentage of households that subscribe to fixed broadband of at least 100 Mbps, calculated as the total use of fixed broadband (source: Eurostat) multiplied by the percentage of fixed broadband lines of at least $100 \mathrm{Mbps}$. Households with fast broadband coverage (NGA), was $90 \%$. This indicator was calculated as the $\%$ of households covered by fixed broadband of at least $30 \mathrm{Mbps}$ of download. The technologies considered are FTTH, FTTB, Cable Docsis 3.0 and VDSL. Very high-capacity fixed network coverage (VHCN) $89 \%$, is \% of households covered by any fixed VHCN. The technologies considered are FTTH and FTTB for 2015-2018 and FTTH, FTTB and Cable Docsis 3.1 for 2019. 4G

Socio-educational gaps derived from the impact of digitization in Spain 2020 point to a STEM and gender-sensitive education. Inés M. González Vidal \& Adriana Gewerc Barujel. Página 11 de 24 
coverage in Spanish homes was $95 \%$, it was measured from the \% of populated areas with $4 \mathrm{G}$ coverage, measured as coverage average number of telecommunications operators in the country. The taking advantage of mobile broadband was $99 \%$, which means the number of mobile data subscriptions per 100 people. The 5G NA readiness was $30 \%$, which means the amount of spectrum allocated and ready for use of $5 \mathrm{G}$ by the end of 2020 within the so-called $5 \mathrm{G}$ pioneer bands. These bands are $700 \mathrm{MHz}(703-733 \mathrm{MHz}$ and $758-788 \mathrm{MHz}), 3.6 \mathrm{GHz}$ (3400-3800 MHz) and $26 \mathrm{GHz}(1000 \mathrm{MHz}$ within 24250-27500 MHz), it should be noted that the three spectrum bands have the same weight. The broadband price index, $51 \%$, this means the broadband price index that measures the prices of representative baskets of fixed, mobile and convergent broadband offers (Russo, 2020; Kwilinski, Vyshnevskyi \& Dzwigol, 2020).

\section{Connectivity and 2 Human capital \\ 1a Fixed broadband take-up, 1b Fixed broadband coverage, 1c Mobile broadband; 2a Internet user skills,2b advanced skills}

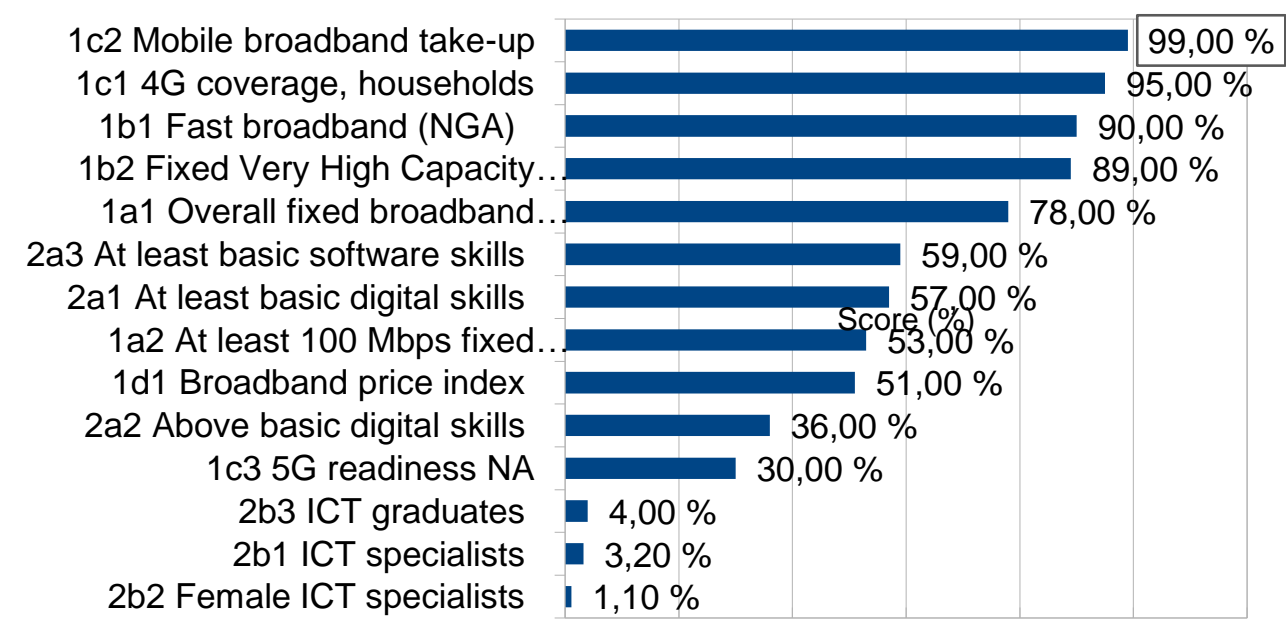

Figure 4 Score of dimensions 1 Connectivity and 2 Human capital.

Connectivity dimension is contrasted with those for Human Capital (Figure 4), a considerable gap is observed between the two dimensions. The most critical values are present in the indicators 1d1 Broadband price index, 2a2 Above basic digital skills, 1c3 5G Preparation NA, $2 \mathrm{~b} 3$ graduates in ICT, $2 \mathrm{~b} 1$ specialists in ICT and $2 \mathrm{~b} 2$ women specialized in ICT. Educational gaps are observed in the acquisition of Internet user skills and advanced skills to be able to quickly meet the demands of the environment (López \& Valle, 2006). 


\subsubsection{Use Internet service}

The Use Internet services dimension includes 11 indicators related to $3 \mathrm{a}$ Internet use, $3 \mathrm{~b}$ Activities online and 3c Transactions (Table 5). The use of Internet services creates additional ways of earning income, it also multiplies social capital and guarantees greater opportunities to find work (Russo, 2020).

Table 5

Dimension of 3 Use Internet service. Source: based on data from Russo (2020).

\begin{tabular}{|l|l|c|}
\hline No & Indicator & Spain score \\
\hline 1 & 3a1 People who have never used the internet & $8,00 \%$ \\
\hline 2 & 3a2 Internet users & $88,00 \%$ \\
\hline 3 & 3b1 News & $78,00 \%$ \\
\hline 4 & 3b2 Music, videos and games & $86,00 \%$ \\
\hline 5 & 3b3 Video on demand & $39,00 \%$ \\
\hline 6 & 3b4 Video calls & $61,00 \%$ \\
\hline 7 & 3b5 Social networks & $65,00 \%$ \\
\hline 8 & 3b6 Doing an online course & $16,00 \%$ \\
\hline 9 & 3c1 Banking & $60,00 \%$ \\
\hline 10 & 3c2 Shopping & $64,00 \%$ \\
\hline 11 & 3c3 Selling online & $15,00 \%$ \\
\hline
\end{tabular}

Analyzing table 4 it is observed that the indicator $3 \mathrm{a} 1$ People who have never used the Internet in Spain is $8 \%$. This result suggests that some population profiles may be practically excluded from digital services and resources because they do not have the means or the skills to participate in a digitally dominated society (Seifert, Cotten \& Xie, 2020). People with inadequate internet connectivity will be at a disadvantage and will experience greater digital exclusion (Seifert, 2020).

Indicator $3 \mathrm{a} 2$ Internet users present a value of $88 \%$, these are people who use the Internet at least once a week. The indicator $3 \mathrm{~b} 1$ News presents a value of $78 \%$, these are people who use the Internet to read news sites, newspapers or online magazines. Indicator 3b2 Music, videos and games obtained a value of $86 \%$, which are the people who used the Internet to play or download games, images, movies or music. $3 \mathrm{~b} 3$ Video on demand indicator, obtained a value of $39 \%$, these are the people who used the Internet to use video on demand services. The indicator $3 \mathrm{~b} 4$ for Video calls obtained a value of $61 \%$, they are the people who used the Internet to make phone calls or video calls (for example, Skype). Indicator 3 b5 Social Networks, obtained a value of $65 \%$, these are the people who used the Internet to participate in social networks (create a user profile, post messages or other contributions). The indicator $3 \mathrm{~b} 6$ Take an online course, obtained a value of $16 \%$, are the people who used the Internet to

Socio-educational gaps derived from the impact of digitization in Spain 2020 point to a STEM and gender-sensitive education. Inés M. González Vidal \& Adriana Gewerc Barujel. Página 13 de 24 
take an online course (on any subject). The 3c1 Banking indicator, with a value of $60 \%$, is the people who used the Internet to use online banking. The indicator $3 \mathrm{c} 2$ Purchases, with a value of $64 \%$, are the people who requested goods or services online. $3 \mathrm{c} 3$ Online sales $15 \%$, representing people who sold goods or services online (Russo, 2020; Kwilinski, Vyshnevskyi \& Dzwigol, 2020).

\section{Use of internet services and 2 Human capital (3a Internet use; 3b Activities online \& 3c Transactions ) and (Internet user skills $2 \mathrm{a}$ and advanced skills $2 \mathrm{~b}$ )}

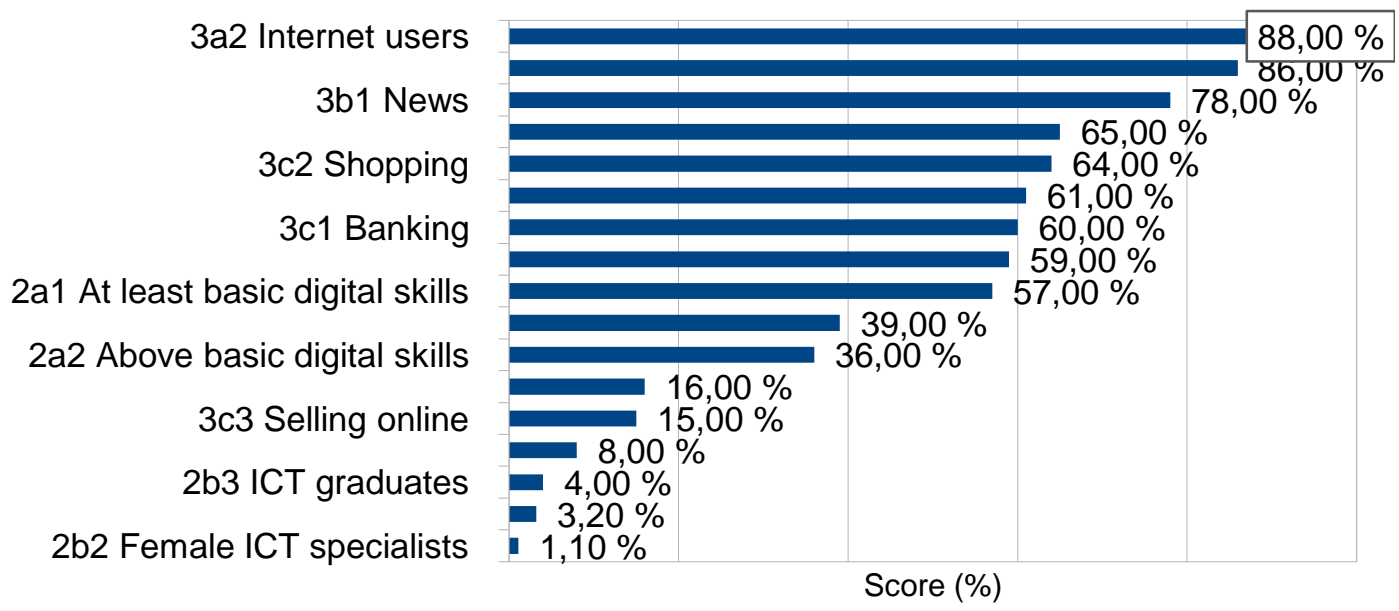

Figure 5 Dimension of 3Use of internet service and 2Human capital.

Source: by the authors based on data from Russo (2020).

If the User of Internet services is contrasted with Human capital, it is observed that the most critical values are present in the indicators $3 \mathrm{~b} 6$ Taking an online course, 3c3 Selling online, $3 \mathrm{a} 1$ people who never use the Internet, $2 \mathrm{~b} 3$ people with less knowledge of software, $2 \mathrm{~b} 1 \mathrm{ICT}$ specialists and women ICT specialists, the latter being the lowest value of all (figure 5).

The analysis of the dimensions (Human Capital and User of Internet services) from a training and educational perspective, showed a link between social exclusion and technology. This leads us to think that information technology skills are linked to technological innovation (Seifert, Cotten \& Xie, 2020; Anttiroiko \& de Jong, 2020; Kwilinski, Vyshnevskyi \& Dzwigol, 2020; Mervyn \& Allen, 2012).

\subsubsection{Integration of digital technology}

The digital technology integration dimension is made up of seven indicators (electronic information, social media, big data, cloud, SMEs (small and medium-sized enterprises) selling online, e-commerce billing, cross-border online sales), these characterize business

Socio-educational gaps derived from the impact of digitization in Spain 2020 point to a STEM and gender-sensitive education. Inés M. González Vidal \& Adriana Gewerc Barujel. Página 14 de 24 
and commercial digitization (table 6). This dimension provides opportunities to run your own business using digital technology resources. Measures to include digitization and other emerging technologies can boost the innovation capacity of the Spanish economy (Rosso, 2020).

Table 6

Dimension 4Integration of digital technology dimension. Source: based on data from Russo (2020).

\begin{tabular}{|l|l|c|}
\hline No & Indicator & Spain score \\
\hline 1 & 4a1 Electronic information sharing & $43,00 \%$ \\
\hline 2 & 4a2 Social media & $29,00 \%$ \\
\hline 3 & 4a3 Big data & $11,00 \%$ \\
\hline 4 & 4a4 Cloud & $16,00 \%$ \\
\hline 5 & 4b1 SMEs selling online & $19,00 \%$ \\
\hline 6 & 4b2 e-Commerce turnover & $9,00 \%$ \\
\hline 7 & 4b3 Selling online cross-border & $7,00 \%$ \\
\hline
\end{tabular}

Analyzing table 5 we found that the indicator of 4a1 Electronic information exchange $43 \%$, means that an ERP (enterprise resource planning) software package was used to share information between different functional areas (for example, accounting, planning, production, marketing). The indicator of $4 \mathrm{a} 1$ Social networks $29 \%$, means that companies use two or more of the following social networks: social networks, blog or microblog of a company, websites to share multimedia content, tools to share knowledge based on wiki. The use of social networks means that the company has a user profile, an account or a user license depending on the requirements and type of social network. The 4a3 Big Data indicator 11\%, companies that analyze big data from any data source. The $4 \mathrm{a} 4$ Cloud $16 \%$ indicator refers to companies that purchase at least one of the following cloud computing services: hosting their database, accounting software applications, CRM software, computing power. 4B1 SMEs that sell $19 \%$ online, refers to SMEs that have at least $1 \%$ of online turnover. Indicator $4 \mathrm{~b} 2 \mathrm{E}$-commerce turnover is $9 \%$, it refers to the total turnover of SMEs through electronic commerce. Indicator $4 \mathrm{~b} 3$ Cross-border online sales obtained a value of $7 \%$ and refers to SMEs that made electronic sales to other EU countries (Russo, 2020; Kwilinski, Vyshnevskyi \& Dzwigol, 2020).

Socio-educational gaps derived from the impact of digitization in Spain 2020 point to a STEM and gender-sensitive education. Inés M. González Vidal \& Adriana Gewerc Barujel. Página 15 de 24 


\section{Integration of digital technology and Human capital (4a Business digitization; 4b e-Commerce) and (Internet user skills $2 \mathrm{a}$, advanced skills $2 \mathrm{~b}$ )}

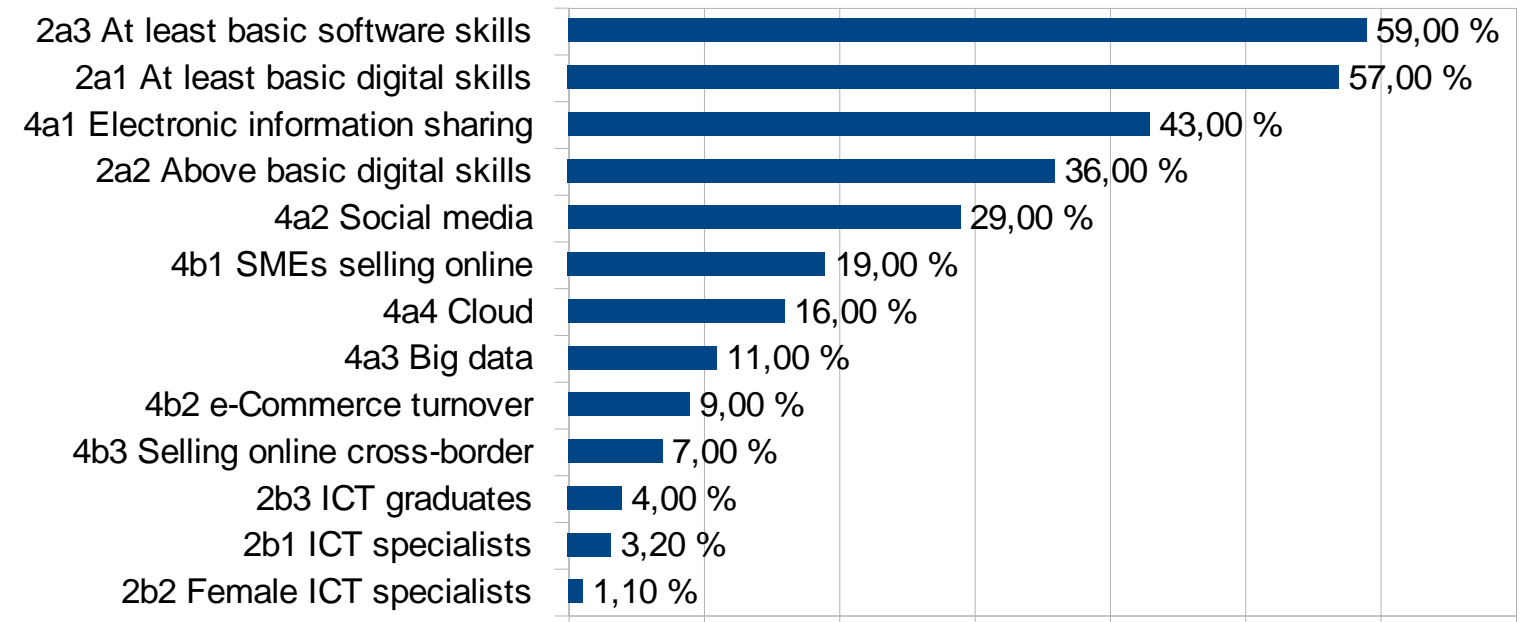

Figure 6 Dimension of 4Integration of digital technology and 2Human capital. Source: by the authors based on data from Russo (2020).

When the integration of digital technology and human capital is contrasted, gaps are observed, related to the indicators of $4 \mathrm{a} 1$ Electronic information exchange, $4 \mathrm{a} 2$ Social networks, 4a4 Cloud, 4b2 E-commerce billing, $2 \mathrm{~b} 3$ ICT graduates and $2 \mathrm{~b} 2$ women specialists in ICT (figure 6).

From the educational point of view, there is evidence of the need to update formal training programs that address the increasing level of digitization in the country and that integrate STEM content as an interdisciplinary method that allows the financial integration of SMEs in the adoption of smart solutions adapting their businesses to the new technological changes in society (Bianchi \& Giorcelli, 2019; Kwilinski, Vyshnevskyi \& Dzwigol, 2020; Martínez Usarralde, 2020).

\subsubsection{Digital public services}

The digital public services dimension measures both the demand and supply of digital public services, as well as open data. Digital technologies have more and more potential, and governments must guarantee and provide a wide variety of benefits to citizens in this regard Russo (2020)

This dimension includes five indicators: e-Government users, Pre-filled forms, Compliance with online services, Digital public services for companies and Open data (table 7), it is characterized by the e-Government domain, allowing companies to reduce costs by

Socio-educational gaps derived from the impact of digitization in Spain 2020 point to a STEM and gender-sensitive education. Inés M. González Vidal \& Adriana Gewerc Barujel. Página 16 de 24 
communicating with authorities and freeing up resources for commercial activities. According to the DESI 2020 report, digital public services ranked well in Spain, showing a very good score well above the European average score.

Table 7

5Digital public services, DESI 2020 in Spain. Source: by the authors based on data from Russo (2020).

\begin{tabular}{|l|l|c|}
\hline No & Indicator & Spain score \\
\hline 1 & 5a1 e-Government users & $82,00 \%$ \\
\hline 2 & 5a2 Pre-filled forms & $80,00 \%$ \\
\hline 3 & 5a3 Online service completion & $96,00 \%$ \\
\hline 4 & 5a4 Digital public services for businesses & $93,00 \%$ \\
\hline 5 & 5a 5 Open data & $90,00 \%$ \\
\hline
\end{tabular}

The indicator 5a1 e-Government users, $82 \%$ refers to SMEs that made electronic sales to other EU countries. Indicator 5a2 Forms filled out $80 \%$, which refers to the people who sent completed forms to public authorities through the Internet in the previous 12 months. $5 \mathrm{a} 3$ completion of online service $96 \%$, which refers to the amount of data that is pre-filled in online forms of public service. 5a4 Digital public services for companies 93\%, which refers to the proportion of administrative steps that can be performed online for important life events (birth of a child, new residence, etc.). 5 a5 Open data 90\%, this indicator broadly reflects the proportion of public services required to start a business and conduct regular business operations that are available online to domestic and foreign users. Services provided through a portal receive a higher score, services that only provide information (but must be completed offline) receive a more limited score. 


\section{Digital public and 2 Human Capital \\ (5a e-Government) and (2 alnternet user skills and $2 b$ advanced skills )}

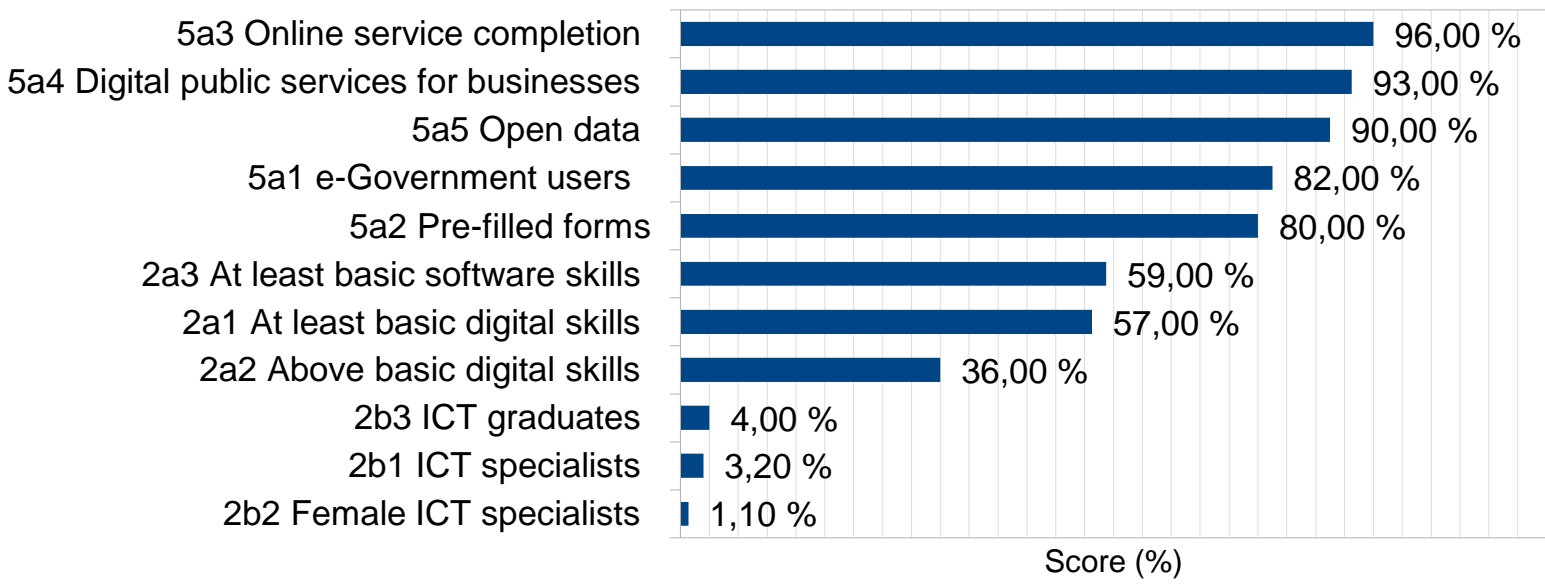

Figure 7 Dimension of Digital public services and Human capital.

Source: by the authors based on data from Russo (2020).

When the values of digital public services and human capital are contrasted. The values show a very large gap between both dimensions, the most critical values are: $2 \mathrm{a} 2$ above basic digital skills, $2 \mathrm{~b} 3$ graduates in ICT, $2 \mathrm{~b} 1$ specialists in ICT and 2b2 women specialists in ICT (figure 7). It is evident that technological innovations have a great impact on contemporary economic, social and educational relations. (Sanci, 2020).

In the DESI 2020 report, Spain ranks second in the EU in digital public services, well above the EU average. A consensus is reached among all public administrations to develop the same interoperable digital infrastructure by default. The indicators show a high level of online interaction between public authorities, citizens and businesses (Russo, 2020). However, if we compare this result with the scores for the Human capital dimension, we find a very large gap.

\section{Discussion}

The year 2020 was marked by health events caused by COVID-19, EU member countries experienced a higher level of digitization in society, which was a great challenge for universities. The COVID-19 crisis demonstrated that digital skills are crucial today, enabling citizens to access information and services over the Internet. The DESI 2020 report summarizes the most important digital performance indicators of European countries in times of pandemic.

This work analyzed the DESI variable composed of 5 dimensions: Connectivity; Human capital; Use of Internet services; Integration of digital technology; and digital public services 
(Russo, 2020). A first study compared the DESI of Spain in relation to the average score of the EU, in the period 2018-2020. Spain obtained a high score in the dimensions analyzed Connectivity, Use of Internet services and Digital public services, with Digital public services being the dimension with the most significant difference. Integration of digital technology in Spain in relation to the average of the EU countries, was observed with a slightly positive trend line and tending to zero, contrasting with the results of the EU (Q1). However, Human capital obtained values below the EU; showed a negative trend line; in the 2019-2020 period with a slight upward trend (Q2). These results visualized possible social and educational gaps related mainly to the Human Capital dimension and the Integration of digital technology in Spain.

The following study delves into the Human capital indicator, the results show low scores for all Human capital indicators compared to the rest (Q3). For example, the lowest scores refer to digital skills superior to basic ones, that is, Graduates in ICT 4.00\%; ICT specialists with $3.20 \%$ and Women ICT specialists with $1.10 \%$. In this sense, in the Related jobs section, some authors warn about the impact of technological change on productivity, the skills of workers. Economic growth and human capital formation have implications for the knowledge economy, so a new human-centered perspective is essential (CEOE, 2017; Psifidou \& Ranieri, 2020; Russo, 2020; Kwilinski, Vyshnevskyi \& Dzwigol, 2020; Bryndin, 2019; Flores, Xu \& Lu, 2020; López and Valley, 2006).

The Integration of digital technology dimension, which is related to business digitization and electronic commerce, was analyzed in the period from 2018 to 2020. This dimension provides opportunities to run your own business using digital technology resources. However, it was observed that the growth line of Spain 2020 in relation to the European average score was almost nil (Q4.3). This result may be justified because some sectors do not have the means or do not have the necessary skills to participate in a digitally dominated society (Seifert, Cotten, \& Xie, 2020, Arkko, 2020).

The dimension Use of Internet services, shown in indicator 3a1 People who have never used the Internet, was $8 \%$. Some previous studies have visualized people who will be at a disadvantage due to inadequate Internet connectivity or because they do not have the necessary skills, these people experience greater digital exclusion (Seifert, Cotten \& Xie, 2020). So, digital exclusion is most evident in those who are most vulnerable. Looking at the opposite category, digital inclusion will be inherent in the concept of providing smart support, especially for vulnerable people to become familiar with smart electronics and participate in an increasingly digitized society (Anttiroiko \& de Jong, 2020) (Q4.2).

The Connectivity dimension in the DESI 2020 report refers to the adoption of fixed broadband, fixed broadband coverage, mobile broadband, and broadband prices. In this case, Spain presented scores above the EU. Having connectivity gives users greater opportunities to use digital skills, Internet services, digital technology, and digital public services. In general, the EU member countries that showed the highest levels of digitization manipulate a more significant reduction in poverty and social exclusion. However, those with inadequate Internet connectivity will be at a disadvantage and experience greater digital exclusion.

Socio-educational gaps derived from the impact of digitization in Spain 2020 point to a STEM and gender-sensitive education. Inés M. González Vidal \& Adriana Gewerc Barujel. Página 19 de 24 
(Bhandari, 2020; Kwilinski, Vyshnevskyi \& Dzwigol, 2020; Anttiroiko \& de Jong, 2020; Bryndin, 2019; Seifert, 2020). In this research, the scores of the Connectivity dimension were contrasted with those of Human Capital, a considerable gap was observed between the two dimensions, in this sense both indicators had very uneven growth in Spain 2020 (Q4.1).

Digital public services and human capital are contrasted and show a very large gap between both dimensions. In 2020, a significant growth was experienced in the levels of digitization in the government context in terms of digital public service in Spain 2020 (Q4.4).

The analysis of the social and educational gaps caused by the impact of the level of digitization in society, the technological change in productivity and the skills of workers, have generated an increase in the gap between education in STEM subjects and new skills and competencies required of Human Capital (Psifidou \& Ranieri, 2020; Roig-Vila, \& Moreno- Isac, 2020; Serra \& Roca-Piera, 2011) (Q5).

\section{Conclusion}

In summary, this study identified educational gaps related to human capital that were: low software skills, few specialists in ICT specialties and even very low values of female representation in ICT specialties. Social gaps were also identified related to people who never use the Internet associated with profiles of the population that are practically excluded from digital services and resources. These results point to the need to update formal training programs that address the growing level of digitization in the country, integrating STEM content and a gender perspective in Education.

These findings lead to the need to implement possible solutions from within the universities. Universities must be able to reinvent themselves and update their training programs as quickly as changes are taking place in the labor market. Educational processes are no longer conceived as an isolated or closed system in relation to its context, which leads to a paradigm break. Hence, the need to articulate new options that allow the contemporary educational system to be perceived as highly interrelated with other subsystems that make up its environment, especially emerging economic subsystems. Technological innovation must be promoted and applied to the educational field, to update Human Capital skills to its highest level, this seems to be fundamental to improve the quality of life in developing countries.

However, STEM content appears to be the key to economic growth and national competitiveness. The STEM approach in education has developed a new way of learning. It is a methodology that links theory and practice and moves away from passive, theoretical and repetitive learning. It makes it possible to simplify study programs, reduce rote learning, and adopt teaching methods that better engage students in more realistic and specialized contexts. Likewise, this type of teaching has implications in aspects of equity and innovation, since it influences the development of the workforce, teaching frameworks, industries, nonformal education, gender gaps, among other aspects.

Socio-educational gaps derived from the impact of digitization in Spain 2020 point to a STEM and gender-sensitive education. Inés M. González Vidal \& Adriana Gewerc Barujel. Página 20 de 24 
The STEM approach to education is essential to improving the ability to compete for highquality jobs. In this sense, it seems very important to consider the gaps related to STEM content with a gender perspective, the DESI 2020 report visualizes the existence of a large gender imbalance in the number of women ICT specialists. A pronounced gender gap in STEM fields at the educational and labor market level. In this sense, a gender-sensitive education must be constantly investigated, due to the long-term consequences on the personal and professional future of female students.

Received: January 1, 2021

Accepted: November 03, 2021

Published: November 30, 2021

González Vidal, I.M., \& Gewerc Barujel, A. (2021). Socio-educational gaps derived from the impact of digitization in Spain 2020 point to a STEM and gender-sensitive education. RED. Revista Educación a Distancia, 21(68). http://dx.doi.org/10.6018/red.465571

\section{Financing}

This work has not received any specific grants from funding agencies in the public, commercial, or non-profit sectors.

\section{References}

Adick, C. (2018). Bereday and Hilker: origins of the 'four steps of comparison'model. Comparative Education, 54(1), 35-48. https://doi.org/10.1080/03050068.2017.1396088.

Almenara, J. C., \& Ortiz, R. V. (2021). STEM y género: un asunto no resuelto. Revista de Investigación y Evaluación Educativa, 8(1), 4-17. https://doi.org/10.47554/revie2021.8.86.

Anttiroiko, A. V., \& de Jong, M. (2020). Conceptualizing Exclusion and Inclusion. In The Inclusive City (pp. 21-40). Palgrave Pivot, Cham. https://doi.org/10.1007/978-3-03061365-53.

Arkko, J. (2020). The influence of internet architecture on centralised versus distributed internet services. Journal of Cyber Policy, 5(1), 30-45. https://doi.org/10.1080/23738871.2020.1740753.

Bianchi, N., \& Giorcelli, M. (2020). Scientific education and innovation: from technical diplomas to university STEM degrees. Journal of the European Economic Association, 18(5), 2608-2646. https://doi.org/10.1093/jeea/jvz049. 
Bianchi, N., \& Giorcelli, M. (2019). Scientific education and innovation: from technical diplomas to university STEM degrees. Journal of the European Economic Association. https://doi.org/10.1093/jeea/jvz049.

Bhandari, V. (2020). Improving internet connectivity during Covid-19. Digital Pathways at Oxford Paper Series, (4). http://dx.doi.org/10.2139/ssrn.3688762.

Briscoe, B., Odlyzko, A., \& Tilly, B. (2006). Metcalfe's law is wrong-communications networks increase in value as they add members-but by how much?. IEEE Spectrum, 43(7), 34-39. https://doi.org/10.1109/MSPEC.2006.1653003.

Bryndin, E. (2019). Creative innovative transformational ecosystem of formation of humane technological society. International Robotics Automation Journal, 5 91-94. https://doi.org/10.15406/iratj.2019.05.00179.

CEOE (2017). La educación importa: libro blanco de los empresarios españoles. Madrid: Confederación Española de Organizaciones Empresariales - CEOE. https://contenidos.ceoe.es/CEOE/var/pool/pdf/publications_docs-file-373-la-educacionimporta-libro-blanco-de-los-empresarios-espanoles.pdf

Chou, C. F., \& Shy, O. (1990). Network effects without network externalities. International Journal of Industrial Organization, 8(2), 259-270.

Cinnamon, J. (2020). Data inequalities and why they matter for development. Information Technology for Development, 26(2), 214-233. https://doi.org/10.1080/02681102.2019.1650244.

Crespí, P., \& García-Ramos, J. M. (2021). Competencias genéricas en la universidad. Evaluación de un programa formativo. Educación XX1, 24(1). https://doi.org/10.5944/educxx1.26846.

Crow, M. (2014). What is the role of universities in global development. The World Bank.

Del Prete, A., \& Almenara, J. C. (2020). El uso del Ambiente Virtual de Aprendizaje entre el profesorado de educación superior: un análisis de género. Revista de Educación a Distancia (RED), 20(62). https://doi.org/10.6018/red.400061.

Deming, D. J., \& Noray, K. (2020). Earnings dynamics, changing job skills, and STEM careers. The Quarterly Journal of Economics, 135(4), 1965-2005. https://doi.org/10.1093/qje/qjaa021.

Díaz, M. J. F. (2005). La innovación como factor de calidad en las organizaciones educativas. Educación XX1, 8(1). https://doi.org/10.5944/educxx1.8.0.343.

Distel, B., \& Lindgren, I. (2019, September). Who Are the Users of Digital Public Services?. In International Conference on Electronic Participation (pp. 117-129). Springer, Cham. https://doi.org/10.1007/978-3-030-27397-2_10.

Flores, E., Xu, X. and Lu, Y. (2020), "Human Capital 4.0: a workforce competence typology for Industry 4.0", Journal of Manufacturing Technology Management, Vol. 31 No. 4, pp. 687-703. https://doi.org/10.1108/JMTM-08-2019-0309.

García-Peñalvo, F. J. (2019). Innovative Teaching Approaches to attract, engage, and maintain women in STEM: W-STEM project. http://repositorio.grial.eu/handle/grial/1787. gender-sensitive education. Inés M. González Vidal \& Adriana Gewerc Barujel. Página 22 de 24 
García-Peñalvo, F. J. (2020). La sociedad del conocimiento y sus implicaciones en la formación universitaria docente. Bosch. http://repositorio.grial.eu/handle/grial/2119.

Gil-Galván, R., Martín-Espinosa, I., \& Gil-Galvan, F. J. (2021). Percepciones de los estudiantes universitarios sobre las competencias adquiridas mediante el aprendizaje basado en problemas. Educación XX1, 24(1). https://doi.org/10.5944/educxx1.26800.

Hynes, E., Locher, M. V., \& Donnet, M. L. L. (2020). Avanzando en el enfoque de género en la ciencia, la tecnología y la innovación= Advancing the gender approach in science, technology and innovation. Cuestiones de género: de la igualdad y la diferencia, (15), 01-06. http://dx.doi.org/10.18002/cg.v0i15.6265.

Hardt, M., \& Negri, A. (2000). Empire. Harvard University Press.

Johnson, C. C., Mohr-Schroeder, M. J., Moore, T. J., \& English, L. D. (Eds.). (2020). Handbook of Research on STEM Education. Routledge, New York.

Kwilinski, A., Vyshnevskyi, O., \& Dzwigol, H. (2020). Digitalization of the EU economies and people at risk of poverty or social exclusion. Journal of Risk and Financial Management, 13(7), 142. https://doi.org/10.3390/jrfm13070142.

López, J. M. V., \& Valle, J. M. (2006). La Unión Europea y su política educativa (Vol. 2). Ministerio de Educación.

Martí Marco, M. R. (2019). Una introducción a los estudios de Educación Comparada en Alemania ("Vergleichende Erziehungswissenschaft"). https://doi.org/10.5944/reec.34.2019.24338.

Martínez Usarralde, M. J. (2020). Inclusión educativa comparada en UNESCO y OCDE desde la cartografía social. Educación XX1, 2021, vol. 24, num. 1, p. 93-115. https://doi.org/10.5944/educXX1.26444.

Mendoza Gamiño, Alejandro (2019): Los saberes de la era digital. Nuevas tecnologías para la práctica humanística: teoría del aprendizaje, bibliotecas digitales y arte terapia (Pontevedra: Editorial Academia del Hispanismo), 161 pp. ISBN: 978-84-17696-12-2. https://doi.org/10.5944/reec.34.2019.25612.

Metcalfe, B. (2013). Metcalfe's law after 40 years of ethernet. Computer, 46(12), 26-31. https://doi.org/10.1109/MC.2013.37.

Mervyn, K., \& Allen, D. K. (2012). Sociospatial context and information behavior: Social exclusion and the influence of mobile information technology. Journal of the American Society for Information Science and Technology, 63(6), 1125-1141. https://doi.org/10.1002/asi.22626.

Mombelli, D. (2019). La metodología comparatista en los estudios literarios. https://doi.org/10.5944/reec.34.2019.24379.

Oppenheimer, S. B., Mills, J. I., Zakeri, A., Payte, T. R., Lidgi, A., \& Zavala, M. (2020). An Approach to Improving Student Success in Science, Technology, Engineering, and Mathematics (STEM) Career Pathways. Ethnicity \& disease, 30(1), 33-40. https://doi.org/10.1080/03075079.2019.1593350.

Powell, J. J. (2020). Comparative education in an age of competition and collaboration. Comparative Education, 56(1), 57-78. https://doi.org/10.1080/03050068.2019.1701248.

Socio-educational gaps derived from the impact of digitization in Spain 2020 point to a STEM and gender-sensitive education. Inés M. González Vidal \& Adriana Gewerc Barujel. Página 23 de 24 
Psifidou, I., \& Ranieri, A. (2020). European cooperation in vocational education and training: towards a common ambition. Revista Española de Educación Comparada, (36), 32-53. https://doi.org/10.5944/reec.36.2020.26879.

Roig-Vila, R., \& Moreno-Isac, V. (2020). El pensamiento computacional en Educación. Análisis bibliométrico y temático. Revista De Educación a Distancia (RED), 20(63). https://doi.org/10.6018/red.402621.

Russo, V. (2020). Digital Economy and Society Index (DESI). European guidelines and empirical applications on the territory. In Qualitative and Quantitative Models in SocioEconomic Systems and Social Work (pp. 427-442). Springer, Cham. https://doi.org/10.1007/978-3-030-18593-0_31.

Sanci, L. (2020). The integration of innovative technologies to support improving adolescent and young adult health. The Journal of Adolescent Health, 67(2), S1.https://doi.org/10.1016/j.jadohealth.2020.05.017.

Seifert, A. (2020). The digital exclusion of older adults during the COVID-19 pandemic. Journal of Gerontological Social Work, 1-3. https://doi.org/10.1080/01634372.2020.1764687.

Seifert, A., Cotten, S. R., \& Xie, B. (2020). A double burden of exclusion? Digital and social exclusion of older adults in times of COVID-19. The Journals of Gerontology: Series B. https://doi.org/10.1093/geronb/gbaa098.

Serra, A. F. G., \& Roca-Piera, J. (2011). Movilidad virtual, reto del aprendizaje de la educación superior en la Europa 2020. Revista de Educación a Distancia (RED), (26). https://revistas.um.es/red/article/view/231941.

Simó, V. L., Couso, D., \& Rodríguez, C. S. (2020). Educación STEM en y para el mundo digital. RED: Revista de Educación a Distancia, (62), 7. https://doi.org/10.6018/red.410011.

Tellhed, U., Bäckström, M., \& Björklund, F. (2017). Will I fit in and do well? The importance of social belongingness and self-efficacy for explaining gender differences in interest in STEM and HEED majors. Sex Roles, 77(1-2), 86-96. https://doi.org/10.1007/s11199-016-0694-y.

Van Dijck, J. (2013). The culture of connectivity: A critical history of social media. Oxford University Press.

Zapata-Ros, M., \& Lévy, P. (2018). Presentación: número especial "Web social y sistemas inteligentes de gestión del aprendizaje en Educación Superior”. http://dx.doi.org/10.6018/red/57/01.

Socio-educational gaps derived from the impact of digitization in Spain 2020 point to a STEM and gender-sensitive education. Inés M. González Vidal \& Adriana Gewerc Barujel. Página 24 de 24 